\title{
Development of an Improved Loop-Mediated Isothermal Amplification Assay for On-Site Diagnosis of Fire Blight in Apple and Pear
}

\author{
Doo-San Shin ${ }^{1 \dagger}$, Gwang-Il Heo ${ }^{1 \dagger}$, Soo-Hyeong Son ${ }^{1}$, Chang-Sik Oh ${ }^{2}$, Young-Kee Lee ${ }^{3}$, and Jae-Soon Cha (iD) ${ }^{1 *}$ \\ ${ }^{I}$ Major in Plant Medicine, School of Applied Plant Science \& Biotechnology, Chungbuk National University, Cheongju \\ 28644, Korea \\ ${ }^{2}$ Department of Horticultural Biotechnology, Kyung Hee University, Yongin 17104, Korea \\ ${ }^{3}$ Department of Agro-food Safety and Crop Protection, National Institute of Agriculture Sciences, Rural Development \\ Administration, Wanju 55365, Korea
}

(Received on March 27, 2017; Revised on May 14, 2018; Accepted on May 17, 2018)

Fast and accurate diagnosis is needed to eradicate and manage economically important and invasive diseases like fire blight. Loop-mediated isothermal amplification (LAMP) is known as the best on-site diagnostic, because it is fast, highly specific to a target, and less sensitive to inhibitors in samples. In this study, LAMP assay that gives more consistent results for on-site diagnosis of fire blight than the previous developed LAMP assays was developed. Primers for new LAMP assay (named as DS-LAMP) were designed from a histidine-tRNA ligase gene (EAMY_RS32025) of $E$. amylovora CFBP1430 genome. The DS-LAMP amplified DNA (positive detection) only from genomic DNA of $E$. amylovora strains, not from either $E$. pyrifoliae (causing black shoot blight) or from Pseudomonas syringae pv. syringae (causing shoot blight on apple trees). The detection limit of DSLAMP was 10 cells per LAMP reaction, equivalent to $10^{4}$ cells per $\mathrm{ml}$ of the sample extract. DS-LAMP successfully diagnosed the pathogens on four fire-blight infected apple and pear orchards. In addition, it could distinguish black shoot blight from fire blight. The Bühlmann-LAMP, developed previously for on-site

\footnotetext{
${ }^{\dagger}$ These authors contributed equally to this work as first authors.

*Corresponding author.

Phone) +82-43-261-2554, FAX) +82-43-271-4414

E-mail)jscha@cbnu.ac.kr

ORCID

http://orcid.org/0000-0001-8569-6462

(c) This is an Open Access article distributed under the terms of the Creative Commons Attribution Non-Commercial License (http:// creativecommons.org/licenses/by-nc/4.0) which permits unrestricted noncommercial use, distribution, and reproduction in any medium, provided the original work is properly cited.
}

Articles can be freely viewed online at www.ppjonline.org. diagnosis of fire blight, did not give consistent results for specificity to $E$. amylovora and on-site diagnosis; it gave positive reactions to three strains of $E$. pyrifoliae and two strains of $P$. syringae pv. syringae. It also, gave positive reactions to some healthy sample extracts. DSLAMP, developed in this study, would give more accurate on-site diagnosis of fire blight, especially in the Republic of Korea, where fire blight and black shoot blight coexist.

Keywords : apple, fire blight, LAMP assay, on-site diagnosis, pear

Handling Associate Editor : Hong, Jeum Kyu

Fire blight, caused by Erwinia amylovora, is a devastating disease and threat for pome fruit (especially apple and pear) production worldwide (Braun-Kiewnick et al., 2011). E. amylovora causes wilting and blight on most of the above-ground parts of host plants, including flowers, leaves, fruits, and branches. Infected areas become brown to black, as if burned by fire, and the plants eventually die from severe infection (Van der Zwet et al., 2012). The disease causes severe economic loss to the growers, because no effective cures are available. Annual loss caused by the disease was estimated as being close to 100 million dollars in the USA (Aćimović et al., 2015).

Fire blight has spread into all of North America, Europe, Australasia, and central Asia since it was reported in the USA in the 18th century (Drenova et al., 2012; Smits et al., 2011; Van der Zwet et al., 2012). In 2015, fire blight occurred in Korea, which had been fire blight free, and an eradication program is being carried out now (Park et al., 
2017). In Korea, black shoot blight, very similar to fire blight, has occurred on apple and pear trees since it was reported on pear trees in 1995 (Rhim et al., 1999). A pathogen causing the disease had been identified as Erwinia pyrifoliae (Kim et al., 1999; Rhim et al., 1999). Symptoms of the black shoot blight are so similar to those of fire blight that the two diseases are very difficult to distinguish (Shrestha et al., 2003).

An effective on-site diagnosis tool is needed for phytosanitary treatments for and eradication of fire blight. Rapid immune-strip-applicable on-site diagnosis of fire blight was developed using polyclonal antibodies against strains of E. amylovora (Braun-Kiewnick et al., 2011) and the strip was commercialized (Ea AgriStrip, BIOREBA AG, Reinach, Switzerland). Although it seemed to be useful for on-site diagnosis of fire blight, it and the similar strip could not distinguish E. amylovora from $E$. pyrifoliae nor diagnose fire blight separately from black shoot blight caused by E. pyrifoliae (Heo et al., 2017). Loop-mediated isothermal amplification (LAMP) is known as the best onsite diagnostic assay, because it is fast, highly specific to a target, and less sensitive to PCR inhibitors in samples (Fang et al., 2010a, 2010b; Kiddle et al., 2012; Notomi et al., 2000). Development of portable apparatus, such as Genie III (OptiGene Ltd, West Sussex, UK), that can detect DNA amplification in LAMP in real time makes the LAMP assay more accessible for on-site diagnosis (Bühlmann et al., 2013).

LAMP assays were developed for fire-blight diagnosis and E. amylovora identification (Bühlmann et al., 2013; Moradi et al., 2012; Temple and Johnson, 2011). The LAMP primers developed by Temple and Johnson (2011) were based on pEA29, which makes it unsuitable for strains of E. amylovora lacking the plasmid. The specificity of E. pyrifoliae, a pathogen of black shoot blight, was not checked in the LAMP developed by Moradi et al (2012). Although a few E. pyrifoliae strains were used for development of Bühlmann's LAMP, it was not verified in orchards for ability to exclude black shoot blight from fire-blight diagnosis.

In this study, a new LAMP assay (named as DS-LAMP) that can diagnose fire blight exclusively on site was developed. Its specificity to E. amylovora and diagnostic performance were tested by comparing it with Bühlmann's LAMP, previously developed LAMP assay for on-site diagnosis of fire blight. DS-LAMP, which gave more specific reactions to E. amylovora and also gave more consistent results in on-site diagnosis of fire blight than the previous developed LAMP assay, would give more accurate on-site diagnosis of fire blight.

\section{Materials and Methods}

Bacterial strains. All 26 strains of bacterial pathogens were used in this study (Table 1). The eight strains of $E$. amylovora and five strains of E. Pyrifoliae were obtained from the Crop Protection Department at the National Academy of Agricultural Science, Rural Development Administration (RDA), in Korea. The other five strains of E. pyrifoliae and eight strains of Pseudomonas syringae pv. syringae that cause shoot blight on apple trees were obtained from the Korean Agricultural culture collection (KACC), RDA, in Korea and Andong National University, respectively. Bacteria were cultured routinely on nutrient agar (NA, Becton, Dickinson \& Co., Sparks, MD, USA) and stored in $\mathrm{a}-70^{\circ} \mathrm{C}$ deep freezer.

LAMP primer design. To find E. amylovora specific LAMP primers, the chromosomal target region (8578 bp containing $7 \mathrm{CDs}$ ), where the primers of the BühlmannLAMP were designed (Bühlmann et al., 2013), was explored. Since the chromosomal target region was found by comparative genomic analysis of 12 strains of $E$. amylovora and 11 strains of non-target bacteria that share the host plants with E. amylovora (Bühlmann et al., 2013), the region was thought to be a good target site for new $E$. amylovora-specific LAMP primers. Several sets of primers were designed from the region with Primer-Explorer V4 software (http://primerexplorer.jp/e/index.html), and specificity to $E$. amylovora of each primer set was tested with the purified DNA from strains of E. amylovora, E. pyrifoliae, and Pseudomonas syringae pv. syringae. One of the primer sets (DS primers) was selected. The DS primers were designed from nucleotide sequences of the histidinetRNA ligase gene (EAMY_RS32025, EAMY_3139 as old locus tag) of E. amylovora CFBP1430 complete genome (accession: FN434113). EAMY_RS32025 is located two genes away from EAMY_RS32035 (EAMY_3135 as old locus tag), where the Bühlmann primers were designed. DS primers consist of five primers, including a loop primer (Table 1). The LAMP developed by Bühlmann et al. (2013) was tested throughout this study to compare its specificity and detection sensitivity for on-site diagnosis.

LAMP assay. The reaction mixture for the LAMP assay developed with DS primers (DS-LAMP) was $25 \mu \mathrm{l}$, containing $1.6 \mu \mathrm{M}$ of inner (FIP/BIP) primers, $0.2 \mu \mathrm{M}$ of outer (F3/B3) primers, $0.8 \mu \mathrm{M}$ of the loop primer, $15 \mu \mathrm{l}$ of isothermal master mix (OptiGene Ltd), and $1 \mu \mathrm{l}$ of the sample extract or $10 \mathrm{ng}$ of purified bacterial genomic DNA. For 
Table 1. Bacterial strains used in this study and their reaction by LAMP assays

\begin{tabular}{|c|c|c|c|c|c|}
\hline \multirow{2}{*}{ Bacterial species } & \multirow{2}{*}{ Strains } & \multirow{2}{*}{ Disease/Host ${ }^{\mathrm{a}}$} & \multirow{2}{*}{ Source $^{b}$} & \multicolumn{2}{|c|}{ LAMP $^{c}$} \\
\hline & & & & DS & Bühlmann \\
\hline \multirow[t]{8}{*}{ Erwinia amylovora } & YKB 12316 & $\mathrm{FB} /$ pear & $\mathrm{RDA}$ & + & + \\
\hline & YKB 12317 & $\mathrm{FB} /$ pear & RDA & + & + \\
\hline & YKB 12318 & FB / apple & RDA & + & + \\
\hline & YKB 12319 & FB / apple & RDA & + & + \\
\hline & YKB 12320 & $\mathrm{FB} /$ pear & RDA & + & + \\
\hline & YKB 12321 & $\mathrm{FB} /$ pear & RDA & + & + \\
\hline & YKB 12322 & FB / apple & RDA & + & + \\
\hline & YKB 12323 & FB / apple & RDA & + & + \\
\hline \multirow[t]{10}{*}{ Erwinia pyrifoliae } & KACC 13945 & $\mathrm{BSB} / \mathrm{nk}$ & $\mathrm{KACC}$ & - & - \\
\hline & KACC 13947 & $\mathrm{BSB} / \mathrm{nk}$ & $\mathrm{KACC}$ & - & $+(1 / 3)$ \\
\hline & KACC 13948 & $\mathrm{BSB} / \mathrm{nk}$ & $\mathrm{KACC}$ & - & - \\
\hline & KACC 13949 & $\mathrm{BSB} / \mathrm{nk}$ & $\mathrm{KACC}$ & - & - \\
\hline & KACC 13952 & $\mathrm{BSB} / \mathrm{nk}$ & $\mathrm{KACC}$ & - & $+(3 / 3)$ \\
\hline & YKB 12324 & BSB / apple & $\mathrm{RDA}$ & - & - \\
\hline & YKB 12325 & BSB / apple & RDA & - & $+(2 / 3)$ \\
\hline & YKB 12326 & BSB / apple & RDA & - & - \\
\hline & YKB 12327 & BSB / apple & RDA & - & - \\
\hline & YKB 12328 & BSB / apple & RDA & - & - \\
\hline \multirow{8}{*}{$\begin{array}{l}\text { Pseudomonas syringae } \\
\text { pv. syringae }\end{array}$} & SHPS 005 & SB / apple & ANU & - & - \\
\hline & SHPS 007 & SB / apple & ANU & - & - \\
\hline & SHPS 022 & SB / apple & ANU & - & $+(1 / 3)$ \\
\hline & SHPS 0056 & SB / apple & ANU & - & - \\
\hline & WSPS 039 & SB / apple & ANU & - & $+(1 / 3)$ \\
\hline & WSPS 042 & SB / apple & ANU & - & - \\
\hline & WSPS 048 & SB / apple & ANU & - & - \\
\hline & WSPS 050 & SB / apple & ANU & - & - \\
\hline
\end{tabular}

${ }^{a}$ FB, Fire blight; BSB, Black shoot blight; SB, Shoot blight; nk, not known.

${ }^{b}$ KACC, Korean Agricultural Culture Collection; RDA, Rural Development Administration; ANU, Andong National University.

'DS-LAMP, this study; Bühlmann-LAMP (Bühlmann et al., 2013): +, positive reaction with 3 replications; -, negative reaction with 3 replications.

comparison of LAMP assay performance between DSLAMP and Bühlmann-LAMP, different inner-primer concentrations were used. The LAMP assay was carried out for $30 \mathrm{~min}$ at $65^{\circ} \mathrm{C}$ with Genie III (OptiGene Ltd). When the amplification peak had not appeared within $30 \mathrm{~min}$, the LAMP assay was considered negative. The LAMP specificity for E. amylovora was tested using $10 \mathrm{ng}$ of purified bacterial genomic DNA. To measure the LAMP detection sensitivity, $0.5 \mathrm{ml}$ of serially diluted bacterial suspensions $\left(10^{8}\right.$ cells $/ \mathrm{ml}-10^{4}$ cells $\left./ \mathrm{ml}\right)$ of $10^{8}$ cells $/ \mathrm{ml}\left(\mathrm{OD}_{600}=0.1\right)$ was added to subcortical tissues (0.1-0.2 g) of healthy pear twigs placed in a plastic bag with $4.5 \mathrm{ml}$ of antioxidant maceration buffer (polyvinylpyrrolidone $20 \mathrm{~g}$, mannitol $10 \mathrm{~g}$, ascorbic acid $1.76 \mathrm{~g}$, reduced glutathion $3 \mathrm{~g}$ in 11 of PBS, pH 7; Gorris et al., 1996). The outside of the plastic bag was hammered lightly with a rubber hammer, and $1 \mu \mathrm{l}$ of the extract was used for the LAMP.

Sample preparation in orchards. Various symptomatic samples were collected, and tissue extracts of the samples were prepared in the same way as for the LAMP detection sensitivity assay. Subcortical tissues (0.1-0.2 g) of twigs and branches showing blight or canker were placed in a plastic bag with $5 \mathrm{ml}$ of antioxidant maceration buffer, and the outside of the bag was hammered lightly with a rubber hammer. The tissue extracts were used in a LAMP assay and pathogen isolation. Tissue extracts of symptomatic leaf and fruitlet were prepared in the same way. Bacterial ooze on fruitlet and twigs were transferred directly into the antioxidant maceration buffer with a sterilized plastic loop. 
Table 2. LAMP primers used in this study

\begin{tabular}{lll}
\hline Target & Primer $^{\text {b }}$ & Sequence $\left(5^{\prime}\right.$ '-3') \\
\hline EAMY $_{-}$ & F3 & ATAATAAGAGAATGGCGCTATG \\
RS32025 & B3 & TCTACATCTCCACCTTTGG \\
(DS primers) & FIP & TAATGAAGTTGAATCTCAGGCATGAGAAAAAATCCATTGTAAAACCTTCG \\
& BIP & GATGGATTGCTTAGTGAGCTCAGCCAATCTCTCCACAACCG \\
& LoopF & AAAGTTGTTTTCATCCCACGGA \\
EAMY & F3 & TCAAGATCGTGTGGCTATG \\
RS32035 & B3 & CTAAAAACCGGGGCAAAC \\
$($Bühlmann's & FIP & ACGRTTCTACCCTTCCTGTCTACTTCTCTGGGGTTTCAGTC \\
primers $\left.{ }^{\text {a }}\right)$ & BIP & ATGTCACCTGATTCTACAGCCGCAATCATTCATGGTTCTGGAC \\
& LoopF & ACATTAGCGGCCCGACCAA \\
& LoopR & CTRTTAAGATGGCATGCAGA \\
\hline
\end{tabular}

${ }^{a}$ Bühlmann et al (2013). ${ }^{b} \mathrm{~F} 3$ and B3, outer primers; FIP and BIP, inner primers; loopF and loopR, forward and reverse loop primers.

Pathogen isolation and identification. Sample extracts prepared in orchards were brought to the laboratory, and serially diluted extracts were plated on the levan medium (yeast extracts $2 \mathrm{~g}$, bactopeptone $5 \mathrm{~g}, \mathrm{NaCl} 5 \mathrm{~g}$, sucrose 50 $\mathrm{g}$, agar $20 \mathrm{~g} / 1$, distilled water 1 1). Mucoid colonies on the levan medium were transferred to MGY (mannitol $10 \mathrm{~g}$, glutamic acid, monosodium salt $2 \mathrm{~g}$, yeast extract $0.25 \mathrm{~g}$, $\mathrm{MgSO}_{4} \cdot 7 \mathrm{H}_{2} \mathrm{O} 0.2 \mathrm{~g}, \mathrm{NaCl} 0.2 \mathrm{~g}, \mathrm{KH}_{2} \mathrm{PO}_{4} 0.5 \mathrm{~g}, 1 \mathrm{~N} \mathrm{NaOH}$ $2.4 \mathrm{ml}$, agar $15 \mathrm{~g} / \mathrm{l}$ ). Colonies showing characteristics of E. amylovora and E. pyrifoliae were pure-cultured and identified by PCRs with E. amylovora-specific primers, PEANT1/2 (Powney et al., 2011) and E. pyrifoliae-specific primers, EpSPF/EpSPR (Shrestha et al., 2007).

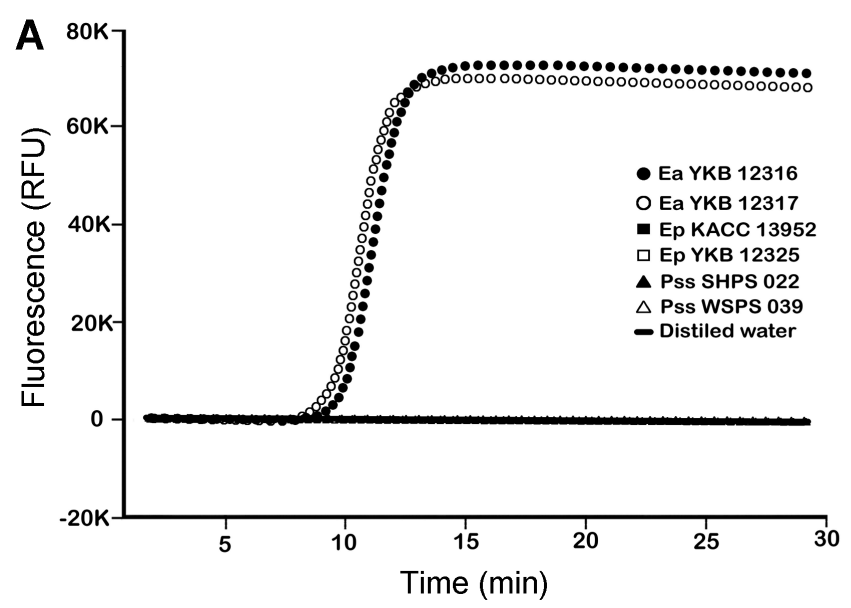

\section{Results}

Specificity and detection sensitivity of LAMP assay. The specificity of the DS-LAMP assay with DS primers designed in this study was first examined. The DS-LAMP assay successfully amplified DNA from all eight strains of E. amylovora used in this study (positive detection), but not from all strains of E. pyrifoliae or $P$. syringae pv. syringae (negative detection) (Table 2, Fig. 1). In contrast, the Bühlmann-LAMP amplified not only from $E$. amylovora strains, but also from four strains of E. pyrifoliae and two strains of $P$. syringae pv. syringae: DNA was amplified in all three

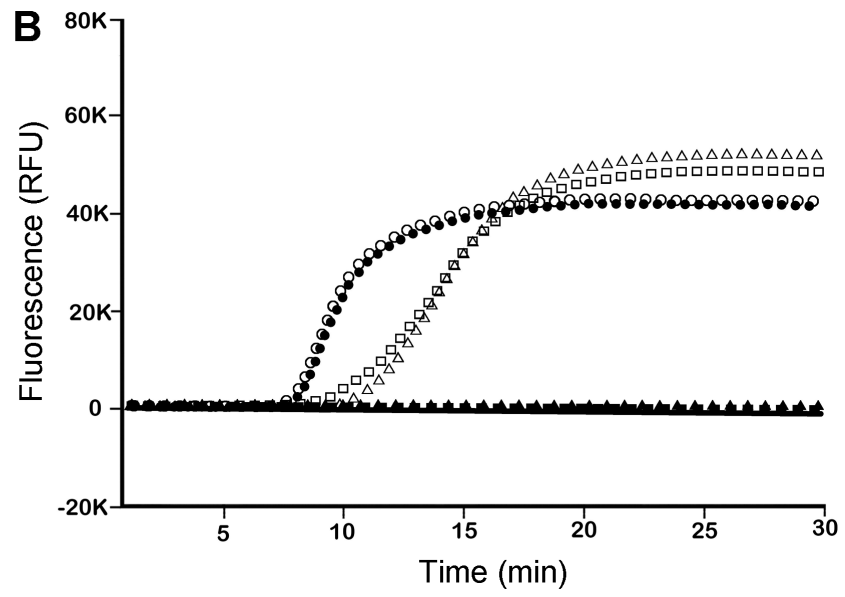

Fig. 1. DNA amplification curves of representative strains of Erwinia amylovora (Ea), E. pyrifoliae (Ep), and Pseudomonas syringae pv. syringae (Pss) by DS-LAMP (A) and Bühlmann-LAMP (B) carried out with Genie III (OptiGene Ltd, West Sussex, UK). Purified genomic DNA (10 ng) was used; Ea YKB 12316 (black circle), Ea YKB 12317 (hollow Circle), Ep KACC 13952 (black square), Ep YKB 12325 (hollow square), Pss SHPS 022 (black triangle), Pss WSPS 039 (hollow triangle). Distilled water was as a negative control (black line). 

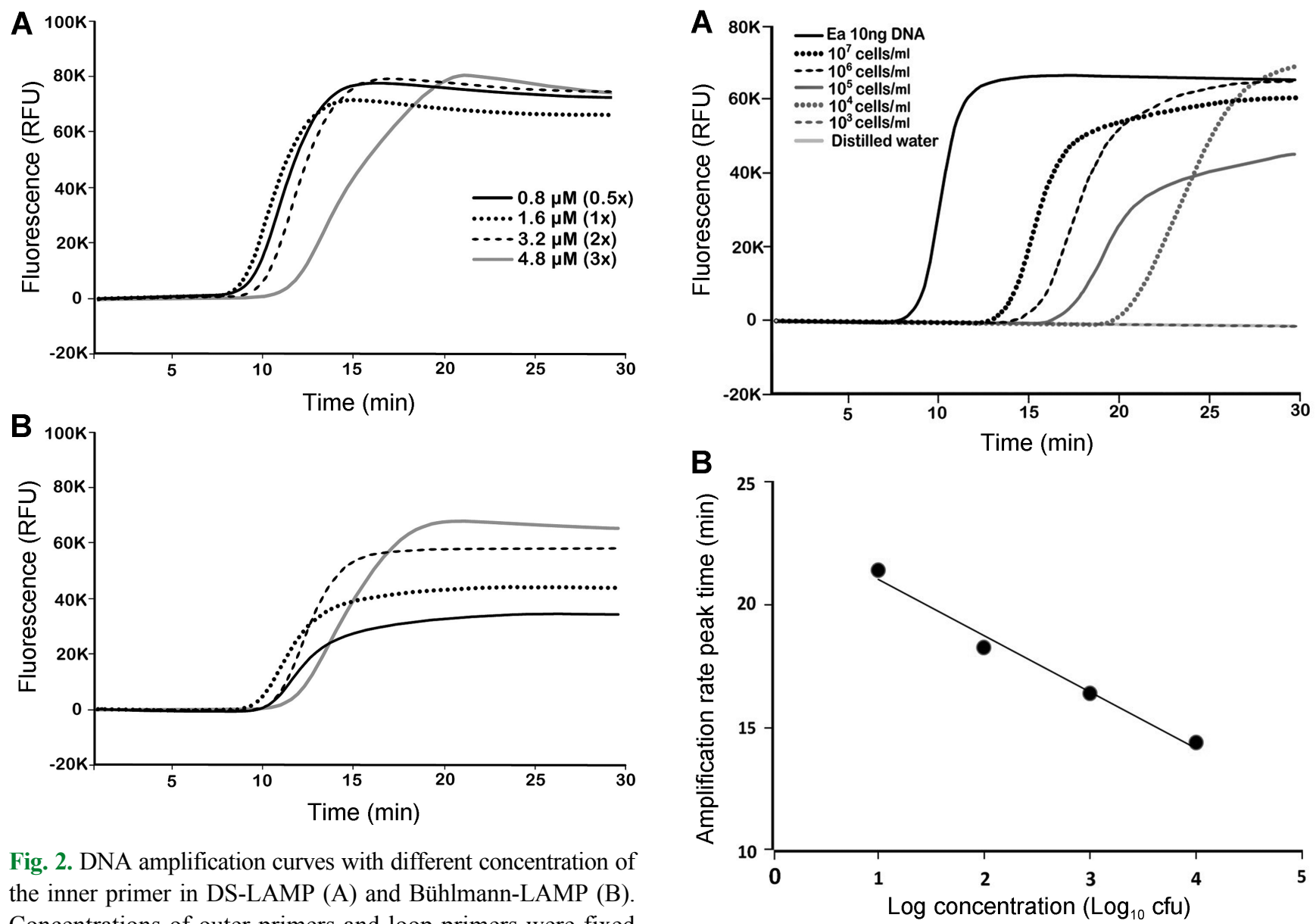

Fig. 2. DNA amplification curves with different concentration of the inner primer in DS-LAMP (A) and Bühlmann-LAMP (B). Concentrations of outer primers and loop primers were fixed at $0.2 \mu \mathrm{M}$ and $0.8 \mu \mathrm{M}$, respectively. The genomic DNA of Ea YKB12316 was used as a DNA template, and LAMP assays were carried out at $65^{\circ} \mathrm{C}$ for $30 \mathrm{~min}$.

replicates for Ep KACC13951 and KACC13952 and in one or two replicates for Ep KACC13947, YKB12325, Pss SHPS022, and SHPS042 (Table 2, Fig. 1). These results indicate that DS-LAMP is very specific to E. amylovora and that the Bühlmann-LAMP specificity for E. amylovora is incomplete. The maximum fluorescence of DS-LAMP was about 20-30 K RFU higher than that of Bühlmann-LAMP in LAMP assays (Fig. 1). In addition, the maximum fluorescence of Bühlmann-LAMP assays was inversely proportional to the inner primer concentrations, and it reached a maximum peak similar to that of DS-LAMP assays (Fig. 2). Incompleteness of the specificity for E. amylovora of Bühlmann-LAMP may result partly from LAMP's intrinsic process.

Detection sensitivity of DS-LAMP was $10^{4}$ cells $/ \mathrm{ml}$ in the sample extract (Fig. 3A). Since $1 \mu 1$ of the sample extract was used in a LAMP assay, the detection limit of DSLAMP was 10 cells per LAMP assay. Regression analysis

Fig. 3. DS-LAMP detection sensitivity to Erwinia amylovora from the sample extracts. The $0.5 \mathrm{ml}$ of serially diluted suspensions of E. amylovora YKB $12316\left(10^{8}-10^{4}\right.$ cells $\left./ \mathrm{ml}\right)$ was pitched in $4.5 \mathrm{ml}$ antioxidant maceration buffer containing subcortical tissues (0.1-0.2 g) of a healthy pear twig placed in a plastic bag. Outside of the plastic bag was hammered lightly with the lubber hammer, and $1 \mu \mathrm{l}$ of the extract was used for DS LAMP (A). Regression curve $(B)$ was $y=-2.285 x+23.325$, and $R^{2}$ was 0.9836 .

showed that there was a linear correlation between bacteria cell numbers pitched in samples and amplification peak time in the range of $10^{7}-10^{4}$ cells $/ \mathrm{ml}$. The regression curve was $y=-2.285 x+23.325$, with 0.9836 of $R^{2}$ value (Fig. 3B).

Performance of DS-LAMP for on-site diagnosis of $E$. amylovora. The DS-LAMP performance for on-site diagnosis of fire blight was verified on the six orchards infected by fire blight ( 2 apple and two pear orchards), black shoot blight (1 apple orchard), and a suspicious but uncharacterized disease (1 pear orchard) in 2016-2017. DS-LAMP detected E. amylovora (positive for fire blight) from the extracts of twigs with cankers collected from two pear 
Table 3. On-site diagnosis of fire blight with DS-LAMP and Bühlmann-LAMP assays

\begin{tabular}{|c|c|c|c|c|c|}
\hline \multirow{2}{*}{ Location } & \multirow{2}{*}{ Host } & \multirow{2}{*}{ Sample $^{\mathrm{a}}$} & \multicolumn{2}{|c|}{ LAMP $^{b}$} & \multirow{2}{*}{ Isolation } \\
\hline & & & Bühlmann & DS & \\
\hline \multirow{4}{*}{$\begin{array}{l}\text { Anseong, Seoun } 1 \\
\text { Dec 13, } 2016\end{array}$} & \multirow[t]{4}{*}{ pear } & Twig with canker-1 & + & + & $\mathrm{Ea}$ \\
\hline & & Twig with canker-2 & + & + & $\mathrm{Ea}$ \\
\hline & & Twig with canker-3 & + & + & $\mathrm{Ea}$ \\
\hline & & Healthy twig & + & - & - \\
\hline \multirow{5}{*}{$\begin{array}{c}\text { Sejong, Bugang } \\
\text { Dec 21, } 2016\end{array}$} & \multirow[t]{5}{*}{ pear } & Twig with canker-1 & - & - & - \\
\hline & & Twig with canker-2 & - & - & - \\
\hline & & Twig with canker-3 & - & - & - \\
\hline & & Branch with canker-4 & - & - & - \\
\hline & & Branch with canker-5 & - & - & - \\
\hline \multirow{4}{*}{$\begin{array}{c}\text { Anseong, Seoun } 2 \\
\text { Jan 11, } 2017\end{array}$} & \multirow[t]{4}{*}{ pear } & Twig with canker -1 & + & + & $\mathrm{Ea}$ \\
\hline & & Twig with canker -2 & + & + & $\mathrm{Ea}$ \\
\hline & & Healthy twig -1 & - & - & - \\
\hline & & Healthy twig -2 & - & - & - \\
\hline \multirow{7}{*}{$\begin{array}{c}\text { Anseong, Miyang } \\
\text { May 17, } 2017\end{array}$} & \multirow[t]{7}{*}{ pear } & Blacken Leafstalk & + & + & $\mathrm{Ea}$ \\
\hline & & Twig with canker & + & + & $\mathrm{Ea}$ \\
\hline & & Trunk with canker & + & + & $\mathrm{Ea}$ \\
\hline & & Healthy leafstalk & + & - & - \\
\hline & & Healthy twig & - & - & - \\
\hline & & Healthy leafstalk & - & - & - \\
\hline & & Healthy branch & - & - & - \\
\hline \multirow{6}{*}{$\begin{array}{c}\text { Cheonan, Seobuk } \\
\text { Jun 8, } 2017\end{array}$} & \multirow[t]{6}{*}{ apple } & Ooze on fruitlet & + & + & $\mathrm{Ea}$ \\
\hline & & Twig with canker & + & + & $\mathrm{Ea}$ \\
\hline & & Trunk with canker & + & + & $\mathrm{Ea}$ \\
\hline & & Ooze on twig & + & + & $\mathrm{Ea}$ \\
\hline & & Blacken leafstalk & + & + & $\mathrm{Ea}$ \\
\hline & & Healthy twig & - & - & - \\
\hline \multirow{6}{*}{$\begin{array}{l}\text { Kwangju, Namjong } \\
\text { Jun 14, } 2017\end{array}$} & \multirow[t]{6}{*}{ apple } & Twig with canker & - & - & Ep \\
\hline & & Blacken leafstalk & - & - & Ep \\
\hline & & Twig with canker & - & - & Ep \\
\hline & & Branch with canker & - & - & Ep \\
\hline & & Healthy twig-1 & - & - & - \\
\hline & & Healthy twig-2 & - & - & - \\
\hline
\end{tabular}

${ }^{a}$ Healthy plant samples collected from healthy trees near diseased trees with typical symptoms

${ }^{b}+$, DNA amplification within 30 min by LAMP assays; -, no DNA amplification within 30 min by LAMP assays

'Isolated pathogens from the sample extracts. Ea, E. amylovora; Ep, E. pyrifoliae; -, no pathogen isolated

orchards, Anseoung, Seoun 1 (Dec 13, 2016) and 2 (Jan $11,2017)$ from which only twig samples were available because it was winter (Table 3). In addition, DS-LAMP detected E. amylovora from three fire-blight symptomatic sample extracts from a pear orchard, Anseoung, Miyang (May 17, 2017) and on apple orchards in Cheonan and Seobuk (Jun 8, 2017). E. amylovora was also detected from two ooze samples from the apple orchard (Table 3). The pathogenic bacterium E. amylovora was actually isolated from all of the symptomatic sample extracts and ooze sam- ples, whereas it was not isolated from any healthy sample extracts (Table 3). DS-LAMP did not amplify DNA from sample extracts of five twigs with cankers from a pear orchard at Sejong, Bugang (Dec 21, 2016), and no pathogen was isolated from the sample extracts (Table 3). The symptoms of the pear tree may have been caused by soil conditions or other environmental factors. DS-LAMP gave negative reactions to four symptomatic sample extracts collected from an apple orchard at Gwangju, Namjong (Jun 14, 2017). However, E. pyrifoliae, a pathogen causing 
black shoot blight, was isolated from the sample extracts; that is, black shoot blight was infecting the apple orchard. These results showed that DS-LAMP diagnosed fire blight successfully on site and can distinguish fire blight from black shoot blight. Bühlmann-LAMP performed much like DS-LAMP for on-site diagnosis of fire blight. However, it gave false positives on two healthy sample extracts from two pear orchards at Anseoung, Seoun 1 and Anseoung, Miyang (Table 3).

\section{Discussion}

Fast and accurate on-site diagnosis is needed to eradicate and manage economically important and invasive diseases such as fire blight. The DS-LAMP developed in this study successfully diagnosed fire blight on fire-blight-infected apple and pear orchards, and distinguished fire blight from black shoot blight, which is very similar to fire blight in terms of its symptoms and pathogen.

DS-LAMP amplified DNA only from E. amylovora, whereas the specificity for E. amylovora of BühlmannLAMP was incomplete in our study. It gave positive signals to several strains of E. pyrifoliae and $P$. syringae pv. syringae. Since only a few non-target pathogens (2 strains of $E$. pyrifoliae, the pathogen of black shoot blight, and none of $P$. syringae pv. syringae, the pathogen of apple shoot blight) were used in Bühlmann et al. (2013), primer nucleotide sequences may be not specific enough for $E$. amylovora. However, the amplification patterns in Bühlmann-LAMP suggest that intrinsic factors of the LAMP process may also be responsible for incompleteness to E. amylovora of the Bühlmann-LAMP. Bühlmann-LAMP gave inconsistent results in replicate experiments, which were performed with E. pyrifoliae KACC13947 and YKB12325, and P. syringae pv. syringae SHPS 022 and SHPS 039; it gave positive reactions only once or twice out of three replicates. Rarely, it gave positive results even in a negative control (extraction buffer only or healthy sample extracts). As shown in the results, the maximum fluorescence of Bühlmann-LAMP was much lower than that of DS-LAMP, although the concentrations of primers used were almost same in both LAMP assays. Moreover, the maximum fluorescences of Bühlmann-LAMP assays were inversely proportional to inner primer concentrations. The primer's suitability for PCR (Sambrook and Russell, 2001), such as $\mathrm{G}+\mathrm{C}$ percentage, $\mathrm{G}+\mathrm{C}$ clamp, self-annealing, hetero-annealing, secondary structure of the amplification region, and nonspecific binding to different sites, of both LAMP primers was not very different. Since the number of loop primers was different, one for DS-LAMP and two for Bühlmann-LAMP, the ef- ficiency of amplicon ladder formation in the recycling step may have made a difference between Bühlmann-LAMP and DS-LAMP.

The detection limit of DS-LAMP for E. amylovora was 10 cells per LAMP reaction $\left(10^{4}\right.$ cells $\left./ \mathrm{ml}\right)$. It is similar to that of Bühlmann-LAMP, in which it was $10 \mathrm{cfu}$ per LAMP reaction using the purified DNA. However, the limit was one order higher with field samples without DNA isolation in Bühlmann-LAMP (Bühlmann et al., 2013). The detection limit of DS-LAMP is 50-100 times higher than that of an immunoassay strip, Ea AgriStrip (BIOREBA $\mathrm{AG}$ ), which is $5 \times 10^{5}-10^{6} \mathrm{cfu} / \mathrm{ml}$ (Product information of AgriStrip). For this reason, DS-LAMP could be more useful for on-site diagnosis in the field. Moreover, the detection sensitivity of DS-LAMP was enough to diagnose on-site in the winter, as shown on the pear orchards at Anseoung, Seoun 1 (Dec 13, 2016) and at Anseoung, Seoun 2 (Jan 11, 2017), indicating that latent infection by E. amylovora could be detected by DS-LAMP assays.

In this study, DS-LAMP diagnosed fire blight in three pear orchards and one apple orchard. The infection of the orchards was confirmed by E. amylovora isolation from the sample extractions, as well as by the Department of Crop Protection, Rural Development Administration (RDA), which has the authority for official pathogen identification for fire-blight diagnosis in Korea. DS-LAMP did not amplify DNA with sample extracts collected from the apple orchard infected by black shoot blight, indicating that it can distinguish fire blight from black shoot blight. The results also showed that DS-LAMP can be used for diagnosis during the winter, when the pathogen population is low in host plants. Since fire blight and black shoot blight are likely to coexist in apple and pear orchards in Korea (Park et al., 2017), DS-LAMP, which can diagnosis fire blight specifically on site will be a very useful tool for sanitary and eradication treatments.

\section{Acknowledgments}

This work was carried out with the support of the Cooperative Research Program for Agriculture Science \& Technology Development (Project No. PJ0117582017) of the Rural Development Administration, Republic of Korea. We thank Prof. Yong Ho Jeon at Andong National University for providing Pseudomonas syringae pv. syringae strains isolated from apple trees.

\section{References}

Aćimović, S. G., Zeng, Q., McGhee, G. C., Sundin, G. W. and 
Wise, J. C. 2015. Control of fire blight (Erwinia amylovora) on apple trees with trunk-injected plant resistance inducers and antibiotics and assessment of induction of pathogenesisrelated protein genes. Front. Plant Sci. 6:16.

Braun-Kiewnick, A., Altenbach, D., Oberhänsli, T., Bitterlin, W. and Duffy, B. 2011. A rapid lateral-flow immunoassay for phytosanitary detection of Erwinia amylovora and on-site fire blight diagnosis. J. Microbiol. Methods 87:1-9.

Bühlmann, A., Pothier, J. F., Rezzonico, F., Smits, T. H. M., Andreou, M., Boonham, N., Duffy, B. and Frey, J. E. 2013. Erwinia amylovora loop-mediated isothermal amplification (LAMP) assay for rapid pathogen detection and on-site diagnosis of fire blight. J. Microbiol. Methods 92:332-339.

Drenova, N. V., Isin, M. M., Dzhaimurzina, A. A., Zharmukhamedova, G. A. and Aitkulov, A. K. 2012. Bacterial fire blight in the Republic of Kazakhstan. Plant Health Research and Practice 1:44-48.

Fang, X., Chen, H., Yu, S., Jiang, X. and Kong, J. 2010a. Predicting viruses accurately by a multiplex microfluidic loopmediated isothermal amplification chip. Anal. Chem. 83:690695.

Fang, X., Liu, Y., Kong, J. and Jiang, X. 2010b. Loop-mediated isothermal amplification integrated on microfluidic chips for point-of-care quantitative detection of pathogens. Anal. Chem. 82:3002-3006.

Gorris, M. T., Cambra, E., Paulin, J. P., Chartier, R., Cambra, M. and Lopez, M. M. 1996. Production and characterization of monoclonal antibodies specific for Erwinia amylovora and their use in different serological techniques. Acta Hortic. 411:47-52.

Heo, G. I., Shin, D. S., Son, S. H., Oh, C. S., Park, D. H., Lee, Y. K. and Cha, J. S. 2017. On-site diagnosis of fire blight with antibody-based diagnostic strips. Res. Plant Dis. 23:306-313.

Kiddle, G., Hardinge, P., Buttigieg, N., Gandelman, O., Pereira, C., McElgunn, C. J., Rizzoli, M., Jackson, R., Appleton, N., Moore, C., Tisi, L. C. and Murray, J. A. H. 2012, GMO detection using a bioluminescent real time reporter (BART) of loop mediated isothermal amplification (LAMP) suitable for field use. BMC Biotechnol. 12:15.

Kim, W. S., Gardan, L., Rhim, S. L. and Geider, K. 1999. Erwinia pyrifoliae sp. nov., a novel pathogen that affects Asian pear trees (Pyrus pyrifolia Nakai). Int. J. Syst. Bacteriol. 49:899-
906

Moradi, A., Nasiri, J., Abdollahi, H. and Almasi, M. 2012. Development and evaluation of a loop-mediated isothermal amplification assay for detection of Erwinia amylovora based on chromosomal DNA. Eur. J. Plant Pathol. 133:609-620.

Notomi, T., Okayama, H., Masubuchi, H., Yonekawa, T., Watanabe, K., Amino, N. and Hase, T. 2000. Loop-mediated isothermal amplification of DNA, Nucleic Acids Res. 28:E63.

Park, D. H., Lee, Y. G., Kim, J. S., Cha, J. S. and Oh, C. S. 2017. Current status of fire blight caused by Erwinia amylovora and action for its management in Korea. J. Plant Pathol. 99:5963.

Powney, R., Beer, S., Plummer, K., Luck, J. and Rodoni, B. 2011. The specificity of PCR-based protocols for detection of Erwinia amylovora. Australas. Plant Pathol. 40:87-97.

Rhim, S. L., Voèlkschb, B., Gardanc, L., Paulinc, J. P., Langlotzd, C., Kimd, W. S. and Geider, K. 1999. Erwinia pyrifoliae, an Erwinia species different from Erwinia amylovora, causes a necrotic disease of Asian pear trees. Plant Pathol. 48:514520.

Sambrook, J. and Russell, D. W. 2001. Molecular cloning: a laboratory manual. CSHL Press, NY, USA.

Shrestha, R., Koo, J. H., Park, D. H., Hwang, I., Hur, J. H. and Lim, C. K. 2003. Erwinia pyrifoliae, a causal endemic pathogen of shoot blight of Asian pear tree in Korea. Plant Pathol. J. 19:294-300.

Shrestha, R., Lee, S. H., Kim, J. E., Wilson, C., Choi, S. G., Park, D. H., Wang, M. H., Hur, J. H. and Lim, C. K. 2007. Diversity and detection of Korean Erwinia pyrifoliae strains as determined by plasmid profiling, phylogenetic analysis and PCR. Plant Pathol. 56:1023-1031.

Smits, T. H. M., Rezzonico, F. and Duffy, B. 2011. Evolutionary insights from Erwinia amylovora genomics. J. Biotechnol. 155:34-39.

Temple, T. N. and Johnson, K. B. 2011. Evaluation of loop-mediated isothermal amplification for rapid detection of Erwinia amylovora on pear and apple fruit flowers. Plant Dis. 95:423430.

Van der Zwet, T., Orolaza-Halbrent, N. and Zeller, W. 2012. Fire Blight, History, Biology, and Management. APS Press, MN, USA. 